\title{
TRAÇOS GENEALÓGICOS NAS DENÚNCIAS DE CORRUPÇÃO NO SEGUNDO GOVERNO BETO RICHA
}

(2014-2018)

\author{
Fernando Marcelino Pereira ${ }^{1}$
}

Resumo: Este artigo tem como objetivo investigar traços familiares das principais denúncias de corrupção conflagradas no segundo governo Beto Richa (PSDB): Operação Voldemort e Publicano em 2015, Operação Quadro Negro em 2016, inquérito apontando irregularidades no Porto de Paranaguá e denúncias da Odebrecht em 2017 e a Operação Lava Jato no início de 2018. Em todos os casos averigua-se a ação do governo Richa, onde família, amigos, compadres, negócios e o governo se unem formando redes de interesses e corrupção.

Palavras-Chave: Governo Richa. Nepotismo. Corrupção. Paraná.

\section{GENEALOGICAL TRACES IN THE COMPLAINTS OF CORRUPTION IN THE SECOND GOVERNMENT BETO RICHA (2014-2018)}

\begin{abstract}
This paper aims to investigate familiar traits of the main corruption allegations in the second Beto Richa government (PSDB): Operation Voldemort and Publicano in 2015, Operation Blackboard in 2016, an investigation pointing out irregularities in the Port of Paranaguá and Odebrecht's denunciations in 2017 and Operation Lava Jato at the beginning of 2018. In all cases the Richa government is investigated, where family, friends, compadres, businesses and the government unite forming networks of interests and corruption.
\end{abstract}

Key words: Richa government. Nepotism. Corruption. Paraná.

*Recebido em 30/05/2018.

*Aceito em 12/06/2018.

\section{Introdução}

No Paraná, apesar de sua imagem "moderna” em comparação com outros Estados, é visível o nepotismo como política dominante desde sua fundação até nossos dias.

\footnotetext{
${ }^{1}$ Bacharel em Relações Internacionais pelo Centro Universitário Curitiba (UNICURITIBA), mestre em Ciência Política e doutorando em Sociologia pela Universidade Federal do Paraná (UFPR). E-mail: fernandomarcelinopereira@gmail.com
} 
Poucas famílias dominam as instituições políticas do Paraná. Difícil seria citar algum governante que não usou e abusou do nepotismo.

O governo Beto Richa não é exceção. Ele próprio é fruto de seu sobrenome.José Richa, pai de Beto Richa, era natural do Rio de Janeiro e formado no curso de Odontologia pela Universidade Federal do Paraná. Apesar de nascido no Rio de Janeiro ocupou vários cargos políticos no Paraná. Participou do movimento estudantil nos anos 50 e tornou-se deputado federal entre 1962 e 1966. Um pupilo de Ney Braga. Em 1972 foi eleito prefeito de Londrina e senador em 1978. Em 1982 foi eleito governador do Estado do Paraná. Seu filho, Carlos Alberto Richa, natural de Londrina e formado em Engenharia Civil pela Pontifícia Universidade Católica do Paraná, iniciou sua trajetória política aos 27 anos quando concorreu sem sucesso ao cargo de vereador em Curitiba. Em 1994 foi eleito Deputado Estadual, se reelegendo em 1998. Nos anos 2000 foi viceprefeito de Curitiba de Cássio Taniguchi, sendo eleito prefeito de Curitiba em 2004 e reeleito em 2008. Em 2010, foi eleito governador do Estado do Paraná e reeleito em 2014. Casou-se com Fernanda Richa, herdeira do conglomerado banco Bamerindus, de Tomas Edson Andrade Vieira. Quando foi prefeito de Curitiba, colocou sua esposa na Fundação de Assistência Social - FAS e seu irmão em uma secretaria municipal. Quando saiu da prefeitura, colocou seu filho, Marcello Richa, ainda estudante de Direito, como secretário municipal na gestão de Luciano Ducci (PSB), posteriormente derrotado na eleição de 2012. Colocou a tia de sua esposa, Maria Christina de Andrade Vieira, como presidenta da Fundação Cultural de Curitiba. Indicou vários parentes de políticos no Instituto PróCidadania de Curitiba (IPCC), entidade privada ligada à FAS em Curitiba ${ }^{2}$.

Quando assumiu o governo estadual em 2011, Beto Richa criou duas supersecretárias: uma de Infraestrutura e Logística e outra de Família e Desenvolvimento Social tendo no comando, respectivamente, o irmão, José "Pepe" Richa Filho - que antes havia sido diretor administrativo do Departamento de Estradas de Rodagem (DER) durante a última gestão do governador Jaime Lerner. O primo Marcos Traad foi para o Detran. O secretário de Turismo do Paraná, Faisal Saleh, é primo de Beto. Luiz Abi Antoun, primo de Beto Richa, que trabalhou com Beto desde quando este foi deputado estadual e depois, continuou trabalhando na Assembleia, cedido, na época ao deputado estadual Hermas Brandão, passou a ser uma eminência parda no governo, extremamente

\footnotetext{
${ }^{2}$ https://www.gazetadopovo.com.br/vida-publica/a-politica-vem-se-tornando-negocio-de-familia-noparana-daedg5khe2xep7latvv9o0kem
} 
ativo no meio empresarial, casado com a jornalista Eloísa Fernandes Pinheiro Antoun, a qual foi vice-presidente da Sercomtel (a empresa de telecomunicações de Londrina).

No início do governo Beto criou 295 novos cargos comissionados, totalizando em salários R \$ 8,6 milhões por ano aos contribuintes paranaenses. Cláudia Queiroz Guedes, a então esposa do presidente da Câmara Municipal de Curitiba, o ex-vereador João Cláudio Derosso (ex-PSDB), foi para a TV Paraná Educativa, atual e-Paraná. José Lupion Neto, irmão do deputado federal Abelardo Lupion (DEMO), na coordenação do Procon. Nelson Cordeiro Justus, filho do ex-presidente da Assembleia Legislativa, deputado Nelson Justus, como diretor na Companhia de Habitação do Paraná. Colocou a nora de Justus como coordenadora de Assuntos Internacionais na Secretaria de Estado da Indústria, do Comércio e Assuntos do Mercosul. Antonio Carlos Salles Belinati, filho do deputado Antonio Belinati (PP), foi alojado na diretoria da Companhia Paranaense de Saneamento (Sanepar). Cassio Taniguchi, do DEM, secretário do Planejamento, o mesmo cargo que o ex-prefeito exerceu no governo Lerner ${ }^{3}$.

Poucos meses após sua reeleição em 2014, o governo Richa passou a ser alvo de uma série de investigações que desnudaram práticas irregulares, na maioria das vezes conectando a família Richa com secretários, empresários e familiares, demonstrando que tipo de interesse atravessa o governo e o poder.

\section{VOLDEMORT E PUBLICANO: o primo distante}

Em março de 2015, o Ministério Público do Paraná (MP-PR) apresentou uma denúncia onde o empresário Luiz Abi Antoun, primo do governador Beto Richa (PSDB). Ele teria liderado um grupo fraudou uma licitação, no valor de R \$ 1,5 milhão, para prestação de serviços de manutenção aos veículos oficiais do Estado do Paraná na região de Londrina.

A atuação do primo de Richa nos bastidores ajudou a batizar a Operação Voldemort. O nome faz alusão a Lord Voldemort, o temido personagem da série literária e cinematográfica Harry Potter, que nos livros de J. K. Rowling é conhecido como "aquele que não deve ser nomeado" ${ }^{4}$. Conforme a promotoria, Antoun teria coordenado a ação entre

\footnotetext{
${ }^{3}$ https://www.brasildefato.com.br/2018/04/06/opiniao-or-politica-no-parana-negocio-de-familia-e-dericos/

4 http://www.redebrasilatual.com.br/blogs/helena/2015/04/imprensa-abafa-operacao-voldemort-esquemade-corrupcao-no-ninho-tucano-3424.html
} 
o início de 2013 e março de 2015. Na denúncia, o Gaeco relata que a Oficina Providence Auto Center, de Cambé, no norte do Paraná, contratada emergencialmente, foi constituída em nome de um "laranja" de Abi Antoun. O MP-PR apontou que, ao fim do contrato emergencial, uma outra empresa venceu a licitação do Governo do Estado para prestar os serviços de manutenção nos automóveis. Para a promotoria, os suspeitos entraram em um acordo com os donos da firma contratada para que a mesma subcontratasse a Providence. Isso foi feito, de acordo com o MP-PR, para permitir "a continuidade da atividade para a qual a oficina foi contratada emergencial e ilegalmente e, de consequência, a permanência do sistema de enriquecimento ilícito concebido pelo grupo"s.

Ao ser deflagrada a Operação Voldemort, em 16 março de 2015, Luiz Abi e outros três investigados chegaram a ser presos preventivamente. Abi, por sua proximidade com o governo e influência política, sustentam os promotores, seria o líder da organização criminosa: "Não há dúvidas de que o réu Luiz Abi atuava como efetivo líder da organização criminosa denunciada, valendo-se de sua influência política e de seu amplo poder econômico para executar os planos por ele engendrados e, assim, alcançar os objetivos almejados por todo o grupo". Ele foi solto sete dias depois, em dia 23 de março após a Justiça conceder um habeas corpus. Alguns meses depois, Luiz Abi passou a responder também ao processo relativo à fase dois da Publicano, deflagrada na mesma época da Voldemort, apurando um esquema de corrupção na Receita Estadual, onde o primo de Beto também exerceria influência, segundo o Ministério Público. Neste caso, Abi teria intermediado a cobrança de propina de empresários para repassar à campanha de reeleição do governador, em $2014^{6}$.

Em agosto de 2015, o Tribunal de Justiça do Paraná (TJ-PR) suspendeu a ação penal da Operação Voldermort. Somente em 20 de outubro de 2015 o Tribunal de Justiça (TJ) autorizou com que a ação penal da Operação Voldemort fosse retomada. Em 288 páginas, os promotores do Grupo de Atuação Especial de Combate ao Crime Organizado (Gaeco) Jorge Barreto da Costa e Leila Schimiti reafirmam, que, de fato, Luiz Abi Antoun, era o verdadeiro dono da Providence, juntamente com o sócio Roberto Tsuneda, e que o mecânico Ismar Ieger é apenas o "laranja". O grupo contava ainda, segundo o

\footnotetext{
5 http://www.gazetadopovo.com.br/blogs/conexao-brasilia/operacao-que-prendeu-primo-de-beto-richa-ebatizada-de-voldemort-ou-aquele-cujo-nome-nao-pode-ser-pronunciado/

6 https://www.folhadelondrina.com.br/politica/investigacao-da-operacao-voldemort-resulta-em-acao-porimprobidade-997229.html
} 
inquérito do Gaeco, com o apoio de um empresário, responsável por intermediar o contato entre os denunciados e por fornecer orientação aos demais envolvidos sobre como proceder na consecução dos crimes. Conforme as investigações, um advogado também auxiliava dando suporte jurídico e aparência de legalidade a todos os atos, inclusive com a fabricação de documentos e com a simulação do processo de dispensa de licitação que culminou com a contratação da Providence ${ }^{7}$.

Em 28 de agosto de 2016, o juiz Juliano Nanuncio, da $3^{\text {a }}$ Vara Criminal de Londrina, no norte do Paraná, condenou o empresário Luiz Abi Antoun no processo. Os réus foram condenados por crimes como organização criminosa, falsidade ideológica e por fraude à licitação. Luiz Abi Antoun foi apontado como chefe do esquema: 8 anos e 5 meses de reclusão mais 5 anos de detenção pelos crimes de organização criminosa, falsidade ideológica e fraude à licitação. Pena inicial em regime fechado. Roberto Tsuneda, sócio de Abi apontado como sócio oculto da empresa Providente: 6 anos e 15 dias de reclusão mais 4 anos e 2 meses de detenção pelos crimes de organização criminosa, falsidade ideológica e fraude à licitação. Pena inicial em regime semiaberto. Ismar Ieger, considerado "laranja" do empresário na oficina usada para a fraude: 4 anos, 6 meses e 21 dias de reclusão mais 4 anos e 2 meses de detenção, pelos crimes de organização criminosa, falsidade ideológica e fraude à licitação. Pena inicial em regime semiaberto. Paulo Roberto Midauar, empresário que teria intermediado o contato entre Ieger e o Deto para que a elaboração da licitação fraudulenta: 4 anos, 4 meses e 15 dias de reclusão mais 4 anos e 2 meses de detenção, pelos crimes de organização criminosa e fraude à licitação. Pena inicial em regime semiaberto. Ernani Augusto Delicato, ex-diretor do Deto apontado como responsável por viabilizar a contratação emergencial da empresa Providence, mediante dispensa de licitação: 4 anos, 4 meses e 15 dias de reclusão mais 4 anos e 2 meses de detenção, pelos crimes de organização criminosa e fraude à licitação. Pena inicial em regime semiaberto. José Carlos Lucca, advogado que prestava orientações jurídicas ao grupo para acobertamento das irregularidades, de acordo com o MP-PR: 6 anos e 15 dias de reclusão mais 4 anos e 2 meses de detenção, pelos crimes de organização criminosa, falsidade ideológica e fraude à licitação. Pena inicial em regime semiaberto. Ricardo Baptista da Silva, policial militar que, segundo a denúncia, ajudou a viabilizar a dispensa ilegal de licitação: 2 anos, 4 meses e 20 dias por fraude à licitação. Pena inicial em regime aberto ${ }^{8}$.

\footnotetext{
7 http://g1.globo.com/pr/norte-noroeste/noticia/2015/03/justica-aceita-denuncia-contra-luiz-abi-e-maisseis-por-fraude-em-licitacao.html

8 http://g1.globo.com/pr/norte-noroeste/noticia/2016/08/sete-reus-da-operacao-voldemort-saocondenados-pela-justica-do-pr.html
} 
Em janeiro de 2018, quase três anos depois da deflagração da Operação Voldemort, em março de 2015, o Ministério Público ajuizou ação por ato de improbidade administrativa contra os acusados de terem fraudado licitação, em dezembro de 2014, para a contratação, pelo Estado, da oficina mecânica Providence, de Cambé, que seria de propriedade de Luiz Abi Antoun, parente do governador Beto Richa (PSDB), mas estava em nome de um "laranja", o mecânico Ismar Ieger. A ação, assinada pelas promotoras Luciane Evelyn Cleto Melluso T. Freitas e Daniela Saviani Lemos, da Promotoria de Defesa do Patrimônio Público de Curitiba, foi protocolada em 13 de dezembro e liminar para suspender o contrato foi deferida no dia seguinte pelo juiz substituto da $1^{\mathrm{a}}$ Vara da Fazenda Pública da capital, Ernani Mendes Silva Filho. São réus, além de Abi e Ieger, Ernani Delicato, ex-diretor do Deto (Departamento de Transporte Oficial), órgão onde a licitação fraudada ocorreu; o advogado José Carlos Lucca, o empresário Paulo Roberto Dias Midauar, Roberto Tsuneda, sócio de Abi, e o policial militar Ricardo Baptista da Silva e a oficina Providence. O magistrado indeferiu o pedido de bloqueio de bens no valor de $\mathrm{R} \$ 299$ mil - total de serviços executados pela Providence, conforme notas fiscais emitidas pela oficina - com o argumento de que tal valor não foi pago pelo governo. Na mesma decisão, o juiz expediu carta precatória para Londrina, onde reside a maior parte dos réus. $\mathrm{Na}$ ação, as promotoras pedem a condenação do réus por violação dos princípios administrativos, enriquecimento ilícito e condutas que causam danos ao erário. As penas previstas na Lei de Improbidade são o ressarcimento, perda da função pública, suspensão dos direitos políticos, além de multa civil. Pelo mesmo fato, os réus foram condenados na esfera criminal. Em agosto de 2016, o juiz da $3^{\text {a }}$ Vara Criminal de Londrina, Juliano Nanuncio, sentenciou Abi a 13 anos de prisão e ao pagamento de multa de mais de R $\$ 190$ mil, sob o entendimento de que Abi era, de fato, o dono da oficina, e liderou a organização criminosa que fraudou a licitação. Os crimes apurados foram organização criminosa, fraude em licitação e falsidade ideológica. Aos demais foram aplicadas penas de dois a seis anos de prisão. Todos recorrem em liberdade. A apelação ainda não foi julgada pelo Tribunal de Justiça.

As relações entre os Antoun e Richa não era apenas familiar. A primeira-dama do Paraná, Fernanda Richa foi sócia da esposa de Luiz Abi, Eloiza Antoun, numa faculdade privada Metropolitana criada em 1999. Na época da fundação da Metropolitana, Fernanda Richa aparece como dona de $30 \%$ do empreendimento, que tinha capital inicial de R $\$ 300$ mil. Ela tinha R $\$ 90$ mil, assim como dois outros sócios. Eloiza Abi Antoun, que aparece 
ainda com o nome de solteira, de Eloiza Fernandes Pinheiro, tinha $\mathrm{R} \$ 30$ mil na sociedade. Em 2002, pouco antes de a faculdade ser vendida para um grupo empresarial de Brasília, a participação de Fernanda Richa já havia subido para R \$ 834 mil. Eloiza Abi Antoun aparecia como sócia minoritária, dona de R\$ 139 mil do capital da empresa. Na época, a Metropolitana tinha capital social de $\mathrm{R}$ \$ 2,6 milhões e já era dividida entre seis sócios. Na última transação localizada pela reportagem, em 2007, a Metropolitana, que hoje se chama Pitágoras, foi vendida para o grupo Kroton por R \$ 18 milhões. Na época, cinco anos após a saída das sócias originais, a instituição contava com pouco mais de 3 mil alunos. Luiz Abi Antoun foi aluno da primeira turma do curso de Jornalismo da faculdade União Metropolitana de Ensino Paranaense. Abi ficou apenas um semestre no curso, numa turma que também tinha Michele Janene, filha do ex-deputado federal José Janene. Nenhum dos dois concluiu o curso. Pelos familiares, Beto Richa deixou de apoiar Alfredo Kiefer para prefeitura de Londrina em 2012. Apoiou Maurício Querino Theodoro, vice em outra chapa, que é casado com Maria Fernandes Pinheiro, a irmã de Eloisa Fernandes Pinheiro Abi Antoun, esposa de Luiz Abi ${ }^{9}$.

O papel do primo Abi no governo Richa ficou mais claro quando foi deflagrada em março de 2015, a Operação Publicano, com o objetivo desarticular organização criminosa formada por auditores fiscais da Receita Estadual do Paraná, contadores e empresários que se uniram para facilitar a sonegação fiscal mediante o pagamento de propina. Além de corrupção, a operação combate crimes de falsidade de documentos e lavagem de dinheiro. De acordo com o Ministério Público do Paraná (MP-PR), uma organização criminosa atuava na Receita Estadual em Londrina cobrando propina de empresários em troca de benefícios fiscais. Conforme a denúncia, auditores fiscais faziam vistas grossas para aliviar multas e irregularidades. Mais de 300 pessoas já foram denunciadas ao longo da operação, entre elas auditores fiscais, empresários, contadores, pessoas consideradas "laranjas" no esquema e um policial civil. Existe a suspeita de que dinheiro desviado da Receita era destinado à campanha do governador Beto Richa(PSDB). Na segunda fase da Operação Publicano, realizada pelo Gaeco, 49 pessoas foram presas por participação no esquema de corrupção na Receita Estadual. Ao todo, 59 mandados de prisão foram expedidos pelo juiz da $3^{\text {a }}$ Vara Criminal de Londrina, Juliano Nanuncio. A quadrilha formada por auditores ficais e empresários teria

\footnotetext{
9 http://www.gazetadopovo.com.br/vida-publica/esposas-de-richa-e-abi-foram-socias-em-faculdade-em-
} londrina-6kyr4cgi3mezu5yrt2b71x2fu 
arrecadado, nos últimos anos, cerca de $\mathrm{R} \$ 1$ milhão mensal em propina. Uns dos presos foi o ex-auditor Márcio de Albuquerque Lima, que já foi delegado da Receita em Londrina, detido em companhia de sua mulher, Ana Paula Pelizari Lima, que estava presa desde maio ${ }^{10}$.

Em junho de 2015 a Promotoria de Defesa do Patrimônio Público de Londrina apresentou denúncia à Justiça contra 125 pessoas envolvidas no esquema descoberto dentro da Receita Estadual. Foram denunciados 57 auditores, nove contadores e 59 "particulares", entre eles empresários e advogados. A denúncia é resultado da segunda fase da Operação Publicano, deflagrada pelo Grupo de Atuação Especial e Combate ao Crime Organizado (Gaeco) no dia dez de junho. O número de denunciados pelo Ministério Público (MP) é ligeiramente maior se comparado aos 112 citados em inquérito concluído pelo Gaeco após a prisão de 68 pessoas ligadas ao esquema de corrupção na Receita Estadual que, somente em 2014, pode ter movimentado R \$ 38,4 milhões. Entre os presos estavam Luiz Abi Antoun e toda a alta cúpula da Receita durante o primeiro mandato do governador (2011-2014). Luiz Abi é apontado pelo Gaeco como o "chefe político" do esquema e é descrito como "eminência parda" do governo do Paraná11.

Investigado pela força-tarefa da Operação Publicado, o esquema onde grupo de auditores da Receita do Paraná cobrava propina de empresários para aliviar o pagamento de tributos. Segundo seu principal delator, o auditor Luiz Antonio de Souza, o esquema tinha como mentor o empresário Luiz Abi Antoun, primo do governador Beto Richa (PSDB). As suspeitas sobre a ação de Abi nos bastidores do governo Richa ganharam força depois que parte do depoimento de um ex-funcionário do governo foi revelada. Marcelo Caramori, que tinha um cargo comissionado no Executivo, afirmando em delação premiada que Abi é "o grande caixa financeiro do governador Beto Richa, incumbindolhe bancar campanhas políticas e arrecadar dinheiro proveniente dos vários órgãos do estado". O delator foi preso em Londrina por exploração sexual de menores. Luiz Antônio de Souza estava grampeado e acabou sendo preso em flagrante no motel com uma menina de 15 anos. Souza foi preso assim como a auditora Ana Paula Lima. Ela é mulher de Márcio de Albuquerque Lima, companheiro de corrida de Richa e ex-chefe de

\footnotetext{
${ }^{10} \mathrm{http}: / /$ politica.estadao.com.br/blogs/fausto-macedo/procuradoria-defende-retomada-de-inquerito-contrabeto-richa/

11 http://www.gazetadopovo.com.br/vida-publica/gaeco-prende-49-e-acusa-parente-de-richa-de-chefiarcorrupcao-na-receita-0367o9otqapgsg4oox0khgn2d
} 
fiscalização do fisco. Segundo outro delator, foi o primo de Richa quem colocou Lima no posto. E era Abi, junto com Ezequias Moreira e Deonilson Roldo que organizavam os esquemas de caixa 2 de Richa $^{12}$.

Em julho de 2015, as operações Publicano (que investiga esquema de fraude fiscal e pagamento de propina a agentes da Receita do Paraná) e Voldemort (que apura o envolvimento de homens fortes do governo do tucano Beto Richa em esquemas de corrupção que implicam a campanha eleitoral e 2014) ganharam um juiz exclusivo. Por determinação da presidência do Tribunal de Justiça do Paraná, o juiz Juliano Nanuncio, da $3^{\text {a }}$ Vara Criminal de Londrina, foi encarregado de despachar exclusivamente sobre as duas investigações em andamento. Em 03 de fevereiro de 2016, a Procuradoria Geral da República (PGR) pediu autorização ao Superior Tribunal de Justiça (STJ) para abrir uma investigação contra o governador Beto Richa (PSDB) para apurar corrupção dentro da Receita Estadual do Paraná, na Operação Publicano. A Operação investiga se dentro da movimentação de R 750 milhões ilegalmente, parte deste valor teria sido destinado à campanha de reeleição do governador em 2014. Em março de 2016, o STJ autorizara o primeiro inquérito contra o governador Beto Richa acerca de esquema de corrupção da Receita Estadual. A acusação é de que $\mathrm{R} \$$ 4,3 milhões desviados tenham financiado a reeleição do tucano, segundo investigações da Operação Publicano. Ministério Público Federal (MPF) defendeu a continuidade da investigação contra o governador Beto Richa (PSDB) por fraudes na Receita Estadual, em parecer enviado ao Supremo Tribunal Federal (STF) ${ }^{13}$.

\section{QUADRO NEGRO: o diretor da secretária de educação}

Deflagrada em 2015, a Operação Quadro Negro começou a apurar um esquema de desvio de dinheiro público de obras de reforma e construção de escolas estaduais do Paraná. Em 21 de julho de 2015, o Núcleo de Repressão a Crimes Econômicos (Nurce), da Polícia Civil do Paraná, prendeu cinco na primeira fase da Operação Quadro Negro.

Nove mandados de busca e apreensão também foram cumpridos em Curitiba, nos bairros do Cabral, Ecoville, Água Verde, Vila Izabel, Cidade Industrial de Curitiba e Centro. Entre os presos estava Maurício Jandi Fanini Antonio, diretor de Engenharia, Projetos e Orçamentos da Secretária da Educação entre 2011 e 2014. De janeiro a junho

\footnotetext{
12 https://www.gazetadopovo.com.br/politica/parana/ezequias-luiz-abi-e-deonilson-operaram-caixa-2-dericha-diz-delator-awg 5 spfrnahvcac5w5fbc $2 \mathrm{mlx}$

13 http://g1.globo.com/pr/parana/operacao-publicano/noticia/2016/12/justica-condena-42-reus-naprimeira-sentenca-da-operacao-publicano.html
} 
de 2015 esteve no comando da recém-criada Fundepar - autarquia do governo estadual que assumiria todas as obras da pasta de Educação. Também foram presos a sóciaproprietária da empresa Valor, Vanessa Domingues de Oliveira, a engenheira da empresa Valor, Viviane Lopes de Souza e o procurador da Valor, Eduardo Lopes de Souza. Na residência dos suspeitos foram apreendidos notebook, pendrives, celulares, mais de R \$ 5 mil e documentos referentes ao patrimônio dos envolvidos. No mandado de busca e apreensão cumprido na sala do ex-diretor do Depo, na Secretaria da Educação, foram apreendidos contratos envolvendo a empresa investigada. A operação teve o apoio do Centro de Operações Policiais Especiais (Cope) e contou com a participação aproximadamente de 50 policiais.

O delegado Renato Figueiroa, que coordena o Nurce, explicou que a investigação foi motivada por documentos encaminhados, à Polícia Civil, pela Secretaria Estadual da Educação, por intermédio da Procuradoria Geral do Estado, apontando irregularidades na construção de escolas estaduais. As investigações do Ministério Público (MP-PR) estimam que o núcleo de corrupção tenha causado um prejuízo superior a $\mathrm{R} \$ 20$ milhões aos cofres públicos. Foram analisados dez contratos firmados entre a empresa Valor e a Secretaria de Estado da Educação, entre os anos de 2011 e 2014. As obras investigadas são nas cidades de Santa Terezinha do Itaipu, Cornélio Procópio, Rio Negro, Campina Grande do Sul (2), Curitiba (2), Coronel Vivida, Joaquim Távora e Ponta Grossa. A empresa chegou a receber aproximadamente $\mathrm{R} \$ 25$ milhões, dos quais a grande maioria correspondia a obras não executadas, de acordo com o Nurce.

Em 22 de setembro de 2015, a Polícia Civil do Paraná deflagrou a segunda fase da operação Quadro Negro. Ao todo, foram 11 mandados de busca em apreensão. As buscas acontecem em quatro estados: Paraná, Santa Catarina, São Paulo e na Bahia. Mais de 20 policiais do Núcleo de Repressão a Crimes Econômicos (Nurce) cumpriram mandados de busca e apreensão em Curitiba, Balneário Camboriú (SC) e Salvador (BA), com o apoio das polícias daqueles estados. Não há, nesta segunda fase, mandados de prisão. O alvo da operação são os bens da empresa Valor Construtora e Serviços Ambientais - responsável por fraudes nas obras em escolas públicas - e de Eduardo Lopes de Souza, apontado como o verdadeiro dono da companhia. Entre os alvos da operação estavam dois imóveis: um apartamento na cidade de Balneário Camboriú, na Avenida Atlântica, avaliado em mais de R 5 milhões, e um flat no município de Salvador. Além disso, a Justiça do Paraná determinou a apreensão de nove veículos - todos de luxo, 
avaliados em mais de $\mathrm{R} \$ 3$ milhões - que teriam sido adquiridos com o dinheiro desviado das obras das escolas públicas. Entre os veículos que foi determinada a apreensão está um Porsche Cupê 911 turbo 2015 supostamente comprado por pouco mais de R\$ 1 milhão.

No dia 8 de setembro de 2017 o ministro Luiz Fux, do Supremo Tribunal Federal (STF), homologou o termo de colaboração premiada do empresário Eduardo Lopes de Souza, dono da Valor Construtora. Com a decisão, o conteúdo da delação poderá ser usado na investigação a cargo da Procuradoria-Geral da República (PGR). No acordo, o empreiteiro se compromete a apresentar provas do que disse e entregar bens, para, em troca, não ser preso e permanecer com tornozeleira eletrônica por dois anos.

A delação premiada de Eduardo Lopes de Souza detalhou o esquema de desvios em obras de escolas estaduais apurado pela Operação Quadro Negro. O empresário detalhou que o ex-diretor da Superintendência de Educação (Sude) Maurício Fanini era um dos operadores do esquema e teria dito que esperava arrecadar R $\$ 32$ milhões com os desvios, para financiar via caixa dois a campanha de Richa, em 2014. Segundo o delator, o "o grosso dos valores" foi desviado diretamente por meio de repasses feitos em dinheiro a Fanini, em 2014. O dinheiro foi repassado pessoalmente por Lopes de Souza, que usou mochilas e caixas de vinho para transportar os maços de cédulas. O construtor relatou que chegou a perguntar ao ex-diretor da Sude se os valores estavam mesmo indo para a campanha de Richa. Fanini teria respondido que sim. Além de Richa, a delação também atingiu outros integrantes da cúpula política do Paraná.

Segundo o delator, a negociação para fraudar o erário era conduzida por Mauricio Fanini, na época diretor da Superintendência de Desenvolvimento Educacional, amigo pessoal e homem de confiança de Richa. Para demonstrar intimidade com o governador, Fanini citava viagens em companhia com Richa. O dinheiro era entregue a Fanini na sede da superintendência. Os primeiros valores chegaram em mochilas. O empresário conta que entrava por uma porta lateral do prédio e deixava a quantia no banheiro da sala do diretor, "ao lado do vaso sanitário". A partir de outro momento, para aumentar a segurança, os valores eram guardados e entregues em caixas de vinho. Os repasses foram efetuados entre abril e setembro de 2014. Fanini era responsável pela elaboração dos relatórios falsos sobre as obras contratadas pela Valor e não realizadas. O plano era arrecadar 32 milhões de reais para a campanha de Richa. Souza vencia as licitações com ofertas $20 \%$ abaixo dos preços médios praticados pelo mercado. Mais tarde, os contratos 
eram reajustados. A Construtora Valor conseguiu sete aditivos que somaram mais de 6 milhões de reais. De acordo com um empresário do setor, era impossível competir com os preços apresentados pela empreiteira. "Não havia lógica. Em alguns casos, chegava a $25 \%$ menos" $" 14$.

Lopes de Souza descreveu pagamento de propina ao presidente da Assembleia Legislativa, Ademar Traiano (PSDB). Em um dos pagamentos, ao ver a mala com dinheiro, Traiano teria perguntado ao empresário se "não pode me dar mais?". O delator também relata pagamento de propina a outros agentes políticos: o deputado da ALEP Plauto Miró (DEM), Durval Amaral, conselheiro do Tribunal de Contas e seu filho o deputado Tiago Amaral (PSB). Quanto ao Tribunal de Contas, ainda segundo o delator, Fanini teria insinuado que seria "bom ter alguém do tribunal com eles". Souza articulou contribuições à campanha a deputado estadual de Tiago, filho do conselheiro do TCE Durval Amaral. Richa nega as acusações e classifica as afirmações do delator de "mentirosas, próprias de um criminoso que busca amenizar sua pena”. Segundo o governador, a própria Secretaria de Educação constatou as irregularidades. O tucano afirma ainda nunca ter tido contato com o empresário e que todas as doações à campanha de 2014 "seguiram a legislação e foram aprovadas pela Justiça Eleitoral"15.

O delator afirmou ainda que, em janeiro de 2015, Fanini o chamou para repassar um recado de Richa: seria necessário repassar mais dinheiro para o esquema. Beto pretendia montar um fundo de campanha para sua candidatura ao Senado em 2018. Os recursos também seriam usados nas campanhas a deputado federal de seu irmão, Pepe Richa, e a deputado estadual do filho Marcelo. Ainda segundo Souza, a Valor pagou um "mensalão" no valor de 100 mil reais até quando o escândalo veio à tona e Fanini foi demitido. Além de Richa, Traiano, presidente da Assembleia Legislativa do Paraná, teria recebido 300 mil reais por meio de caixa 2, em três parcelas de 100 mil. Duas delas teriam sido levadas em malas até o gabinete do deputado. A outra teria sido entregue em sua residência. Em uma das entregas, detalha Souza, havia uma quantia a mais. Ao perceber

\footnotetext{
14 http://www.aen.pr.gov.br/modules/noticias/article.php?storyid=85906\&tit=Policia-Civil-deflagrasegunda-fase-da-Operacao-Quadro-Negro

15 https://www.cartacapital.com.br/revista/969/o-mensalao-de-beto-richa
} 
a diferença, o deputado quis saber se o empreiteiro não poderia aumentar o valor do repasse. Resposta: a diferença "estava prometida para a campanha do governador"16.

O repasse a Valdir Rossoni somaria 460 mil reais. "Quando ele me via, me chamava no canto e falava 'e aí, Eduardo, tem coisa boa pra mim hoje?', esfregando as mão", contou o delator aos procuradores do Ministério Público Federal. No depoimento, o empresário afirma ter sido Rossoni quem o apresentou a Fanini. Confirmou ainda que as primeiras obras públicas executadas por sua empresa foram realizadas em $2011 \mathrm{em}$ Bituruna, no sul do Paraná. Coincidentemente, Bituruna é o reduto eleitoral da família Rossoni. Valdir e seu filho Rodrigo foram prefeitos da cidade. Diversos parentes fazem parte do governo municipal. O herdeiro enfrenta problemas com a Justiça. O juiz da $1^{\mathrm{a}}$ Vara da Fazenda Pública de União da Vitória, Luis Mauro Lindemeyer Eche, determinou o bloqueio de seus bens em face das denúncias do Ministério Público, por ter, supostamente, atuado para direcionar uma licitação na reforma de uma escola no município. A obra foi realizada em 2011 e a construtora responsável era a Valor. Teria sido Rossoni que indicou a Valor para fazer parte do esquema ${ }^{17}$.

A Valor Construtora, "nasceu” em 2010, a partir do pedido de recuperação judicial de outra empresa, EGC Construtora e Obras. A Valor iniciou seus trabalhos com a locação de maquinário pesado. A partir de 2012, a empresa começou a tomar novos rumos, com a licitação para a construção de uma escola em Bituruna. A construtora foi a única a participar. Sem concorrentes, a representante da Valor apenas se sentou à mesa do responsável pela abertura dos envelopes e viu a empresa ser aprovada. $\mathrm{O}$ edital não exigia "acervo técnico", ou seja, a empresa não precisava contar com trabalhos anteriores do mesmo gênero para a assinatura do contrato. Depois de fazer esta e de ganhar outras licitações em Bituruna, a Valor construiu seu "acervo técnico" e pôde começar a participar de concorrências no governo do estado ${ }^{18}$.

Em janeiro deste 2016, o Ministério Público (MP) do Paraná abriu investigação sobre os contratos firmados entre a prefeitura de Bituruna e a empresa Valor Construtora e Serviços Ambientais. O proprietário da empresa, Eduardo Lopes de Souza, e outras 14

\footnotetext{
$16 \mathrm{http} / /$ www.gazetadopovo.com.br/politica/parana/quadro-negro-avanca-para-outras-18-escolas-e-miramais-13-construtoras-6qqowtj5pgkgc1600x3i2q8gx

17 https://www.gazetadopovo.com.br/politica/parana/secretario-de-richa-indicou-construtora-envolvidana-quadro-negro-revela-depoimento-1 sc592fw1niqkkui47bd94hx0

$18 \mathrm{http} / /$ www.gazetadopovo.com.br/vida-publica/mp-investiga-contratos-da-valor-construtora-embituruna-00a9e7q9a7gxlvqyvfyne37xs
} 
pessoas, já respondem a uma ação criminal, no âmbito da Operação Quadro Negro. Na denúncia, os 15 réus são acusados de envolvimento em esquema de desvio de dinheiro público a partir de contratos da construtora com a Secretaria de Estado da Educação (Seed). Quase R \$ 20 milhões teriam sido desviados de construções e reformas de escolas estaduais em todo o Paraná. Pelas obras em Bituruna, a Valor recebeu R \$ 6,5 milhões em 7 contratos assinados em 2012. Os recursos saíram dos cofres do Estado, através de convênios do Município com a Seed e também com a Secretaria de Desenvolvimento Urbano $(\mathrm{Sedu})^{19}$.

Valdir Luiz Rossoni nasceu em Empoçado, distrito de Palmas, no CentroSul do Paraná, sendo filho de Cândido e Olga Rossoni. É formado em matemática pela Universidade Estadual de Ponta Grossa e foi em Bituruna, cidade desmembrada de Palmas, que deu início à vida empresarial, no ramo do agronegócio e na política. Eleito prefeito de Biturana entre 1983 e 1989 e em 1991 conseguiu seu primeiro mandato como deputado estadual. Foi presidente da Assembleia Legislativa do Paraná, entre os anos de 2011-2014. Em 2014 foi eleito Deputado Federal pelo PSDB. Em 26 de maio de 2015, renunciou ao cargo de presidente regional do PSDB do Paraná, após ofender uma professora pela por uma rede social. Em março de 2016 foi nomeado Secretário Chefe da Casa Civil do Paraná, no mandato do governo Beto Richa, substituindo Eduardo Sciarra.

A trajetória de Rossoni é cheia de escândalos, especialmente nos seis mandatos consecutivos (24 anos) na Alep (Assembleia Legislativa do Paraná), onde os interesses familiares sempre foram importantes. Empregou a filha Mariana Mariani Rossoni que em 2004 recebia $\mathrm{R} \$$ 11.280. Em um único ano ela recebeu $\mathrm{R} \$ 113$ mil. Este privilégio também foi dado ao seu filho, Rodrigo Rossoni, que recebia R\$ 25 mil em 2003 para ocupar função que lhe foi confiada pelo pai. A irmã de Valdir, Otília Rossoni Silveira, também participava do gabinete. Em 2002 ela ganhava R \$ 18 mil para exercer atividades em favor do político. A filha de Otília e sobrinha de Rossoni, Carla Roberta Silveira, também ocupou cargo comissionado, tendo sido nomeada e exonerada três vezes entre 2005 e 2009. É isso o que revelam os registros de cargos comissionados ocupados no Legislativo do Estado e outros documentos comprobatórios reunidos pelo jornalista aposentado Sylvio Sebastiani, ex-servidor da Alep e então presidente da Asaalep

\footnotetext{
${ }^{19} \mathrm{http}: / /$ www.gazetadopovo.com.br/vida-publica/eleicoes/2014/justica-indefere-candidatura-de-eleita-embituruna-23hlg7rjo6io3x4mrh0hmfexa
} 
(Associação dos Servidores Aposentados da Assembleia Legislativa do Estado do Paraná).

Rodrigo Rossoni, filho do deputado Valdir Rossoni, seguiu os passos do pai e se elegeu prefeito em Bituruna em 2011. Após sete meses de mandato, teve o mandato cassado por abuso de poder econômico na campanha. De acordo com a denúncia, Rodrigo gastou quase o triplo da arrecadação tributária mensal de Bituruna, que conta com 12 mil eleitores. Foram contratados 528 cabos eleitorais, o equivalente a 11,44\% dos 4.614 votos que recebeu durante o pleito suplementar ou a 5,45\% do total de votos válidos computados $(9.682)^{20}$. Após a condenação, Robertinho que ficou em $2^{\circ}$ lugar na eleição suplementar assumiu o cargo. Na disputa das eleições 2012, Robertinho foi novamente candidato e mais uma vez encontrou um "Rossoni" no meio caminho. Dessa vez, ele concorreu contra Cathiane Rossoni, esposa de Rodrigo Rossoni. Com 5.840 votos, Cathiane foi eleita nas urnas ${ }^{21}$.

No caso Diário Secretos de 2010, dentre os quase mil servidores e ex-funcionários da Assembleia Legislativa do Paraná (Alep) que foram investigados pelo Ministério Público do Paraná (MP), 13 suspeitos de serem fantasmas foram contratados pelo gabinete do presidente da Casa, o então deputado Valdir Rossoni (PSDB). Estão na lista dos investigados o atual diretor-financeiro do Legislativo, Sérgio Brun, e dois familiares do deputado: a filha Mariana Mariani Rossoni e o marido dela, Francisco Gaida Junior. Além do grupo de 13, outra servidora ligada a Rossoni é alvo de investigação por suspeita de ter sido fantasma. Conforme mostrou a Gazeta do Povo, a funcionária Hellena Luiza Valle Daru - mãe de Altair Carlos Daru, ex-diretor-administrativo da Assembleia e homem de confiança de Rossoni por dez anos - admite nunca ter trabalhado no Legislativo, embora estivesse lotada no gabinete de Rossoni e tenha recebido $\mathrm{R} \$ 331 \mathrm{mil}$ em salários. Com a denúncia, o filho dela foi demitido por Rossoni da diretoria da Casa. A mãe alega que não sabia que havia sido admitida para trabalhar na Assembleia e Daru é suspeito de tê-la contratado sem que ela soubesse ${ }^{22}$.

\footnotetext{
$20 \mathrm{http} / /$ www.gazetadopovo.com.br/vida-publica/justica-cassa-mandato-de-rodrigo-rossoni-em-bituruna7z8ml8tkdhmquu670rnzv3zv2

${ }^{21} \mathrm{http} / /$ www.gazetadopovo.com.br/vida-publica/eleicoes/2014/justica-indefere-candidatura-de-eleita-embituruna-23hlg7rjo6io3x4mrh0hmfexa

22 http://www.gazetadopovo.com.br/vida-publica/13-servidores-de-rossoni-sao-investigados4z9nz62zgks1527nojox14pji
} 
Em 17 de setembro de 2017, o ex-diretor da Secretaria do Estado de Educação do Paraná (Seed) Maurício Fanini foi preso. A prisão preventiva foi realizada pelo Grupo de Atuação Especial de Repressão ao Crime Organizado (Gaeco) e fez parte da terceira fase da Operação Quadro Negro. A ação do Gaeco partiu de novas denúncias de lavagem de dinheiro contra Fanini e a esposa, a fonoaudióloga Betina Sguario Moreschi Antônio, que, submetida a medidas cautelares, teve seu passaporte retido. Foram executados mandados de busca e apreensão na casa da família, no bairro Cabral, e no atual local de trabalho de Fanini, em Guaratuba. Os mandados foram expedidos pela $9^{\text {a }}$ Vara Criminal de Curitiba e foram apreendidos computadores, documentos, celulares e outros objetos. Maurício Fanini já havia sido preso temporariamente em 2015, quando foi deflagrada a Operação Quadro Negro, e respondia ao processo em liberdade. Desta vez, a prisão teve prazo indeterminado. Com Fanini ficou claro que as irregularidades em construção ou reformas de colégios paranaenses não se restringem à Valor. Outras cinco construtoras tiveram obras embargadas e foram condenadas, juntas, a devolver $\mathrm{R} \$ 6,9$ milhões, entre recursos estaduais e federais.

Em 27 de setembro de 2017, o empresário Iolmar Ravanelli, dono da Construtora M.I., afirmou à Justiça que pagou R\$ 100 mil em propinas para Maurício Fanini. As declarações constam no acordo de delação premiada, que ele firmou junto à Justiça de Curitiba. De acordo com Ravanelli, ainda em 2014, Fanini o procurou, pedindo a propina. "Na primeira medição que a gente fez, já estávamos com alguns dias [de atraso], que daí para considerar de atraso, de encaminhamento de medição, começaram alguns pedidos. Nós estávamos nos aproximando das eleições de 2014 e houve um pedido de que a empresa tinha que colaborar com uma quantia de R $\$ 100$ mil”, afirmou. Ele também disse que à época não tinha o dinheiro para entregar. Questionado pelos investigadores, Ravanelli, ele afirmou que quem fez os pedidos foi Fanini. Ainda segundo ele, após o pagamento, foram emitidos laudos que consideravam as obras em pleno andamento, o que acarretou na liberação de recursos do governo para a Construtora M.I.. De acordo com ele, as medições eram falsas.

As investigações da Operação Quadro Negro apontaram que a equipe chefiada por Fanini na Secretaria da Educação era responsável por produzir relatórios fraudulentos sobre o andamento de obras para a construção de escolas. Inicialmente, a apuração foi realizada nos contratos envolvendo a Construtora Valor, cujo dono também fez acordo de delação premiada. No caso da M.I., a situação também foi alvo de investigações. O 
empresário contou que fez os pagamentos pessoalmente a Fanini. "Eu cheguei, como outras vezes que eu chegava com a minha pasta, e acabei tirando de dentro da pasta e entreguei para ele, dentro de um envelope. O mesmo simplesmente pegou o envelope e guardou no armário dele. E não se falou mais no assunto", afirma. No depoimento prestado à Justiça, Ravanelli afirmou que não sabe Fanini era o destinatário final do dinheiro, mas que ouviu que seria uma doação para campanha política. "Não, não era [doação] oficial. Também não sei para quem era. Simplesmente, ele me falou que era uma contribuição para campanha, que ele tinha uma meta, uma cota lá para atender”, lembra. Ainda conforme o empresário, houve pelo menos mais um pedido para o pagamento de propina. Foi quando a M.I. tentava firmar mais dois contratos aditivos com o governo, para levantar dinheiro e entregar as obras. "Ele [Fanini] falava que ele precisava de R\$ 100 mil de cada aditivo, para sair", contou. Ravanelli disse que não aceitou pagar os valores e que os aditivos nunca foram assinados. No depoimento, o empresário afirmou que todo o dinheiro pago pelo governo do estado foi encaminhado para as obras em Guarapuava. Apesar disso, as obras das escolas Leni Marlene Jacob e Pedro Carli estão paradas e ainda não foram entregues. Se estivessem funcionando, as duas unidades atenderiam 3,2 mil estudantes ${ }^{23}$.

Em 9 de outubro de 2017, a juíza Danielle Mota Comar, responsável pelos processos da Operação Quadro Negro, em primeira instância, determinou o envio de uma das ações penais envolvendo o ex-diretor da Secretaria da Educação, Maurício Fanini, ao Superior Tribunal de Justiça (STJ), em Brasília. A decisão foi motivada pelo pedido de liberdade feito pela defesa de Fanini, preso na terceira fase da investigação. Segundo a juíza, os advogados do ex-diretor alegaram que o cliente está formalizando um acordo de delação premiada com a Procuradoria-Geral da República (PGR). Entre as pessoas citadas por ele estaria o governador do Paraná, Beto Richa (PSDB).

O STJ é o responsável por julgar casos envolvendo governadores de estado. Quando o STJ decide que o caso deve continuar sendo analisado pela Corte, todos réus que já respondem ao processo passam a contar com o direito ao foro privilegiado, neste caso por causa das citações a Richa. Comar afirmou no despacho que, segundo informações repassadas por Fanini, Beto Richa tinha acesso informações privilegiadas, pois sabia com antecedência que o ex-diretor seria preso temporariamente no início da

$23 \mathrm{http} / / / \mathrm{www} \cdot$ bemparana.com.br/tupan/novo-delator-da-quadro-negro-diz-que-pagou-propina-a-exdiretor-da-secretaria-da-educacao-do-parana-que-esta-preso/ 
Operação Quadro Negro. Ela diz ainda que "haveria documentos dando conta dos indicativos de atos ilícitos". Ela classifica Fanini como "longa manus" do governador, ou seja, a pessoa que executava ordens repassadas por Richa. Para a juíza, o envio do processo ao STJ é motivado por uma situação “excepcional”, pois há "relevância e relação desses fatos [investigados] com o chefe do poder executivo estadual”. As informações da defesa de Fanini "implicam, em tese, o Chefe do Executivo Estadual, considerando que pode ter este sido, supostamente, conivente ou participante das ações, em tese, ilegais, é de se decidir deste modo e neste estágio processual" 24 . Além disso, a delação também envolve o conselheiro Durval Amaral, atual presidente do Tribunal de Contas do Estado do Paraná (TCE-PR), que também têm foro especial no STJ.

No início de novembro de 2017, o ministro Herman Benjamin, do Superior Tribunal de Justiça (STJ), encaminhou os processos da Operação Quadro Negro ao ministro Luiz Fux, do Supremo Tribunal Federal (STF). Fux já estava tratando do assunto desde o surgimento do nome do deputado federal Valdir Rossoni, que está licenciado do mandato para ocupar a cadeira de secretário-chefe da Casa Civil no governo do Paraná. Rossoni tem foro especial no STF por causa do mandato. Dias depois, em 17 de novembro de 2017, o Ministério Público do Paraná afastou o promotor Carlos Alberto Choinski, um dos responsáveis por inquéritos da Operação Quadro Negro. Choinski estava protocolando sete ações cíveis contra os envolvidos (à exceção do governador e do presidente da Assembleia, contra os quais só mesmo o procurador-geral pode representar) no esquema de facilitação de desvio de verbas da Educação para a construção de escolas (nunca concluídas) em conluio com a construtora Valor ${ }^{25}$.

Em dezembro de 2017, Maurício Fanini propôs uma delação premiada entregue à Procuradoria-Geral da República (PGR) onde afirma ter recebido dinheiro para não comprometer o Beto Richa na operação Quadro Negro. Fanini afirmou ter recebido uma "mesada"de $\mathrm{R} \$ 12$ mil, valor que teria sido por pelo empresário Jorge Atherino - o Grego - por ordem do governador do Paraná. Os valores começaram a ser pagos após a saída de Fanino da presidência da Fundepar, em junho de 2015. Além do "cala a boca" com

\footnotetext{
${ }^{24}$ http://agoralitoral.com.br/noticias/processo-operacao-quadro-negro-vai-pro-stj/

${ }^{25} \mathrm{https}$ ://contraponto.jor.br/o-mp-deve-respostas-sobre-quadro-negro/
} 
mesadas, Fanini também teria detalhado viagens feitas junto com o governador e que teriam sido pagas por empresários com negócios junto ao Estado ${ }^{26}$.

Em 1 de fevereiro de 2018, a Polícia Federal (PF) ouviu 14 pessoas investigadas na Operação Quadro Negro apurando o desvio de R \$ 20 milhões na construção e reforma de escolas do Paraná. Dentre eles, um especial assessor e dois secretários do governador Beto Richa (PSDB). O secretário de Cerimonal e Relações Internacionais, Ezequias Moreira, conhecido pelo caso da "sogra fantasma" na ALEP. O secretário de Comunicação, Deonilson Roldo, e o assessor da governadoria, Ricardo Rached, também foram ouvidos. A eles foi apresentado um questionário enviado pelo Supremo Tribunal Federal (STF), com até 60 perguntas. Os três foram citados em delação premiada pelo empresário Eduardo Lopes de Souza, dono da Construtora Valor, que venceu sete contratos para obras nas escolas. $\mathrm{O}$ empresário afirmou que entregou para Maurício Fanini (ex-diretor de Secretaria de Educação) cerca de R\$ 12 milhões desviados das obras da Valor na Secretaria de Educação, para ser destinados à campanha à reeleição do governador Beto Richa. O empresário afirmou ainda que ouviu de Fanini que os três principais arrecadadores do "caixa dois" eram Ezequias Moreira, Luiz Abi Antoun, parente do governador, e Deonilson Roldo. O dono da Construtora Valor também disse que Fanini repassava parte do dinheiro para Ezequias Moreira e parte para Abi. Às vezes, afirmou ele, o pagamento era feito para Ricardo Rached ${ }^{27}$. Outro que prestou depoimento foi Gerson Nunes da Silva, atual chefe de gabinete do secretário estadual da Casa Civil, Valdir Rossoni (PSDB). O advogado de Gerson, José Cid Campelo Filho, afirmou que Gerson não tinha conhecimento a respeito da maioria dos fatos que lhe foram perguntados, mas que respondeu todas as questões. Outro depoente ligado ao poder público é Eduardo Paim, que foi chefe de gabinete de Rossoni. Também foram ouvidas a ex-secretária da Valor, Vanessa Domingues, e a ex-advogada da Valor, Úrsula Ramos. A PF ainda vai ouvir mais quatro investigados neste caso - entre eles, o ex-secretário de Administração, Luiz Eduardo Sebastiani. O teor dos depoimentos tomados ainda está sob sigilo. Os interrogatórios serão enviados ao $\mathrm{STF}^{28}$.

\footnotetext{
26 http://www.bemparana.com.br/noticia/542003/ex-aliado-diz-ter-recebido-dinheiro-para-naocomprometer-beto-richa-em-investigacao

27 https://g1.globo.com/pr/parana/noticia/secretario-de-cerimonial-do-parana-recebeu-parte-do-dinheirodesviado-de-escolas-afirma-delator.ghtml

28 https:/g1.globo.com/pr/parana/noticia/pf-ouve-secretarios-e-assessor-de-beto-richa-na-operacaoquadro-negro.ghtml
} 


\section{PARANAGUÁ E ODEBRECHT: o sócio grego}

Além de aparecer na Operação Quadro Negro, Jorge Atherino, o Grego, também aparece em denúncias no Porto de Paranaguá e no recebimento propina na Odebrecht, sempre agindo em favor da família Richa em diversos negócios e empreendimentos ${ }^{29}$.

Em março de 2017, a ministra do Superior Tribunal de Justiça Nancy Andrighi autorizou a abertura de novo inquérito para investigar o governador Beto Richa (PSDB). O processo, que corre em segredo de Justiça tem relação com supostas fraudes no Porto de Paranaguá. O pedido de abertura de inquérito foi feito pelo vice-procurador-geral da República, José Bonifácio Andrada, que aponta suspeitas de corrupção na concessão de licença ambiental pelo Instituto Ambiental do Paraná (IAP) ${ }^{30}$.

O procedimento tem relação com a Operação Superagui realizada no porto de Paranaguá. A Procuradoria Geral da República pediu o compartilhamento de provas coletadas em busca e apreensão autorizada pela $1^{\text {a }}$ Vara Criminal de Paranaguá. O procurador também pediu que fossem ouvidos depoimentos o presidente do Instituto Ambiental do Paraná (IAP), Tarcísio Mossato Pinto, o chefe do departamento de licenciamento e atividades florestais do IAP, Venilton Pacheco Mucillo, e o empresário Theodócio Jorge Atherino, sócio da empresa Green Logística $^{31}$.

A investigação do Ministério Público encontrou indícios de favorecimento ilícito à família Richa na compra de um terreno de grande porte, próximo à Serra do Mar, um mês antes do Eixo Modal de Paranaguá ser criado por decreto do governador. O comprador foi o amigo próximo do governador Jorge Atherino.

Jorge é sócio da R. F. Participacoes Ltda, Eros Empreendimentos Imobiliarios, Trtn Locacoes de Maquinas Ltda e Krisso Agropecuaria Ltda - ME. Suas parentes Flora Leite Atherino, Roberta Leite Atherino e Nicole Leite Atherino também são sócias. Nicole Leite Atherino é sócia destas quatro empresas e também da Green Company (Green Company Empreendimentos Imobiliarios Ltda), Rancho Flora Cafe (Rancho Flora Cafe Ltda - ME), Green Portugal - Scp (Green Loteamento e Empreendimentos Imobiliarios Ltda - Scp).

\footnotetext{
${ }^{29}$ https://contraponto.jor.br/mister-green-o-grego/

30 https://g1.globo.com/politica/noticia/stj-autoriza-inquerito-para-investigar-governador-beto-richa-doparana.ghtml

31 https://g1.globo.com/politica/noticia/stj-autoriza-inquerito-para-investigar-governador-beto-richa-doparana.ghtml
} 
A família de Teodósio Jorge Atherino e de Richa foram sócias nas empresas Green Gold, RF Participações e Green Logística. Segundo as investigações, a Green Logística foi a empresa beneficiada com o decreto assinado por Richa. Em novembro de 2013, a empresa pediu ao IAP uma licença prévia, para construir um estacionamento de caminhões, em uma área de mata atlântica, às margens da BR-277. O local fica próximo ao Porto de Paranaguá. Um mês depois, a Green Logística comprou o terreno onde pretendia construir a obra. No mês seguinte, Richa asssinou o decreto, considerando de interesse público o eixo modal de Paranaguá, que incluía a área do estacionamento. $\mathrm{O}$ texto diminuiu as restrições ambientais para o funcionamento de postos de combustíveis, armazéns e estacionamentos. O Ministério Público disse que essas atividades não são reconhecidas como de utilidade pública e nem de interesse social.

Em fevereiro de 2014, com base no decreto de Richa, o IAP concedeu a licença prévia à Green Logística e a empresa começou a desmatar uma área de aproximadamente 13 hectares, para iniciar a obra e construir ali um estacionamento de caminhões e containers. A área de Mata Atlântica é vizinha de um parque nacional e tem espécies em extinção. Pelo decreto, o local passou a ser de utilidade pública, o que flexibilizou as restrições de caráter ambiental. Também foram autorizadas diversas atividades, como o estacionamento de veículos. A licença, porém, foi suspensa, a pedido do Ministério Público ${ }^{32}$.

De acordo com o Ministério Público do Paraná, que iniciou as investigações, a Green Logística não cumpriu as exigências para começar a obra, mas ainda assim obteve a autorização do IAP. O relatório de vistoria foi assinado por Venilton Pacheco Mucillo. Em um depoimento de julho de 2014, Mucillo citou uma conversa na sala da presidência do IAP, com o presidente do órgão, Tarcísio Mossato Pinto, em que teria sido informado pelo de que a licença do estacionamento era de interesse do governador e da primeira-dama, Fernanda Richa. Mucillo também confessou o envolvimento em um esquema de corrupção dentro do IAP. O chefe do IAP dise que recebeu $\mathrm{R} \$ 100$ mil para facilitar a emissão da licença para a Green Logística. Segundo ele, o dinheiro foi oferecido por um homem que tinha o apelido de Grego, que mais tarde o identificou como o empresário Jorge Atherino, dono da Green Logística. Naquele depoimento, Mucillo afirmou que ao receber a suposta propina de Atherino, o empresário the pediu para esquecer tudo o que sabia, para não comprometer ninguém. O promotor que conduziu o interrogatório ainda perguntou o que deveria ser esquecido e Mucillo respondeu: "A história do governador". O funcionário do IAP afirmou que, embora Jorge Atherino aparecesse como o

32 https://g1.globo.com/pr/parana/noticia/documentos-apontam-que-beto-richa-teria-se-beneficiado-delicenca-ambiental-ilegal.ghtml 
responsável pela Green Logística, ele atuava na verdade como um "testa de ferro" do governador ${ }^{33}$.

As investigações mostraram que Jorge Atherino é um dos donos de um grupo de empresas que levam o nome "Green". No caso da Green Logística, a companhia apresenta uma estreita relação com outras empresas que têm a primeira-dama e os filhos do governador como sócios. Para os investigadores, há indícios de simulação para ocultar os verdadeiros sócios das empresas. Uma dessas empresas que têm negócios com a Green Logística é a BFMAR. Para o Ministério Público, as iniciais da empresa fazem referência à família do governador. F seria Fernanda, M de Marcelo, A de André e R de Rodrigo. Os promotores dizem ainda que não há como não se cogitar que o B significa Beto ${ }^{34}$.

Filho de Theodócio Jorge Atherino, reitor da UFPR entre 1973 e 1977, Jorge sempre conviveu com poderosos no Paraná. Os ex-governadores João Elísio Ferraz de Campos e Mário Pereira também estão no seu rol de amigos. Mário Pereira, por exemplo, teve como chefe do cerimonial do Palácio Iguaçu sua irmã Chica Atherino.

O Grego também apareceu como operação de caixa 2 de Beto Richa e do PSDB. Quando o governador Beto Richa apareceu na lista da Odebrecht, vazada em 23 de março de 2016, de acordo com a planilha encontrada na casa de Benedicto Barbosa da Silva Junior, o governador do Paraná recebeu R \$ 160 mil não declarados no Tribunal Superior Eleitoral como doação da Odebrecht no dia 24 de setembro de 2010, véspera das eleições. O CNPJ anotado na planilha é do diretório regional do PSDB no Paraná (81.183.253/0001-40). Pela planilha, Beto Richa receberia R 200 mil, mas teriam sido depositados R\$ 160 mil numa conta na agência Visconde do Banco do Brasil, em Curitiba. Diversos outros políticos do PSDB estão nesta lista, como Aécio Neves, José Serra e Geraldo Alckmin. Os políticos paranaenses Ratinho Junior, Gustavo Fruet, Luciano Ducci, Ricardo Barros e Luiz Carlos Hauly também apareceram entre os nomes citados na lista ${ }^{35}$.

Benedicto Júnior, ex-presidente da Odebrecht Infraestrutura, citou em seu acordo de delação em dezembro de 2016 quatro repasses não declarados à Justiça Eleitoral para campanhas eleitorais do governador Beto Richa (PSDB). Segundo o delator, o codinome usado para se referir ao governador do Paraná foi "piloto", em três dos repasses. Em outros quatro repasses o apelido

\footnotetext{
33 https://g1.globo.com/pr/parana/noticia/pgr-comeca-a-ouvir-testemunhas-em-inquerito-que-investiga-ogovernador-do-parana-beto-richa.ghtml

34 https://g1.globo.com/pr/parana/noticia/pgr-comeca-a-ouvir-testemunhas-em-inquerito-que-investiga-ogovernador-do-parana-beto-richa.ghtml

${ }^{35} \mathrm{http}: / /$ www.terrasemmales.com.br/lava-jato-imprensa-poupa-beto-richa-na-lista-da-odebrecht/
} 
usado foi "brigão". Segundo as delações de Benedicto e de Valter Lana, ex-executivo da Odebrecht na Região Sul, no total Richa recebeu R \$3.050.000 nas três últimas campanhas. Aos procuradores, o delator deu detalhes sobre os valores doados, as negociações com tesoureiros de campanha e também sobre as intenções da empresa com doações para políticos. Em um dos trechos, ele diz que, em 2014, um executivo da Odebrecht no Paraná foi procurado pelo comitê de reeleição de Richa, pedindo a doação. No vídeo do depoimento, o ex-executivo detalha os pagamentos. "Esses pagamentos foram encaixados, foram planejados e executados dentro do nosso sistema "Drousys", estruturado pelo setor de operações estruturais da Odebrecht. A gente adotou um codinome "piloto" para esse pagamento, como uma menção ao doutor Beto Richa. E os pagamentos foram executados nas datas 09/09/14, R\$ 500 mil, 18/09/14 R\$ 1 milhão e 25/09/14 R\$ 1 milhão". Ainda de acordo com o delator, foram realizados três pagamentos. "Foram autorizados R \$ 4 milhões e foram realizados R \$ 2,5 milhões", explicou. O delator contou, ainda, que há comprovantes desses pagamentos ${ }^{36}$.

Na delação BJ disse que o valor foi "alocado" às obras da rodovia PR-323, cujo responsável o irmão Pepe, que acabou não indo adiante, disse o delator. Segundo ele, se o projeto tivesse sido desenvolvido, "esse valor seria alocado como custo dessa obra". BJ também afirmou que foram pagos $\mathrm{R} \$ 550$ mil por meio de caixa dois - sendo R $\$ 450$ mil em 2010, quando Beto foi eleito governador, e R\$ 100 mil em 2008, quando ele venceu a reeleição para a prefeitura de Curitiba. As doações foram pedidas por Fernando Ghignone, então tesoureiro das campanhas. Nessas ocasiões, os pagamentos foram operacionalizados por Valter Lana e o codinome com "Brigão"37.

O vice-procurador-geral da República, José Bonifácio Andrada, pediu para que o Superior Tribunal de Justiça (STJ) abrisse inquérito para investigar o envolvimento de Beto Richa, citado na delação premiada de executivos da empreiteira Odebrecht e está na segunda lista do Procurador-Geral da República, Rodrigo Janot, de políticos com foro privilegiado que devem ser investigados. Os delatores afirmam que o governador recebeu valores da empreiteira via caixa 2. O intermediador foi quem? O grego.

Em maio de 2017, a divulgação dos depoimentos da JBS pelo Supremo Tribunal Federal (STF) também colocou Beto Richa no rol de políticos supostamente beneficiados pela empresa. À Procuradoria-Geral da República (PGR), Ricardo Saud, diretor de

\footnotetext{
36 https://g1.globo.com/pr/parana/noticia/delacoes-da-odebrecht-codinome-de-beto-richa-psdb-era-pilotosegundo-ex-executivo.ghtml

37 https://www.folhadelondrina.com.br/politica/ministro-do-stj-autoriza-inquerito-para-investigar-betoricha-980251.html
} 
Relações Institucionais e Governo da empresa, afirmou ter entregue pessoalmente $\mathrm{R} \$ 1$ milhão em espécie a Pepe Richa. A entrega do dinheiro teria ocorrido no carro do irmão do governador, na porta de um supermercado em Curitiba. No anexo 36 da delação, Pepe é citado como "emissário de Beto Richa"38. Alguns anos antes, em janeiro de 2014, a empresária Ana Cristina Aquino acusou o secretário de Infraestrutura e Logística do Paraná, Pepe Richa, irmão do governador Beto Richa, de receber a suposta propina de R\$ 500 mil para apoiar a criação do grupo AGX Log no Paraná. De acordo com a empresária, Pepe Richa e Amaury Escudero, representante do escritório do governo paranaense em Brasília, iriam pressionar a montadora Renault para fechar um contrato com a transportadora. Ainda conforme Ana Cristina, as isenções fiscais concedidas à Renault seriam utilizar para conseguir o contrato ${ }^{39}$.

O papel do incorporador Jorge Atherino no governo Beto Richa parece se aprofundar a cada nova investigação. Ruth Bolognese também apurou que um dos empreendimentos imobiliários com a inicial Green na Região Metropolitana de Curitiba, o maior deles, com 1 mil e 800 lotes, o Green Silver, se situa exatamente na margem por onde passa o novo asfalto que liga São José dos Pinhais a Fazenda Rio Grande e cuja obra foi autorizada pelo governador Beto Richa em março de 2017. O Green Silver tem como sócia a família Sanson, dona dos hotéis Caravelle, Curitiba Palace Hotel e Palace Hotel $\mathrm{Slim}^{40}$. Conforme Ruth Bolognese, outros negócios de Jorge também aparentam ter irregularidades:

\footnotetext{
O mesmo padrão de negócios de Atherino ocorreu na Região Metropolitana de Curitiba. Em 28 de março de 2017, o governador Beto Richa homologou o projeto de pavimentação de um trecho de quatro quilômetros de uma via rural no bairro do Agaraú, em São José dos Pinhais, no trecho que liga o município a Fazenda Rio Grande. Além da pavimentação, obras de melhorias como iluminação, construção de calçadas e rampas de acessibilidade. Os recursos, de R\$ 5,5 milhões, foram financiados pelo Banco Regional de Desenvolvimento do Extremo Sul (BRDE), com contrapartida do município de São José dos Pinhais. A área total da obra é de cerca de $90 \mathrm{mil} \mathrm{m}^{2}$. A obra era necessária para a população, vital para os dois municípios e o governo fez o seu papel. O que chama a atenção é a série de empreendimentos imobiliários feitos pela Green RF Participações - nada menos que 7 grandes loteamentos, todos com a marca Green, entre lotes e áreas para a construção de barracões industriais. E justamente nessa região da Região Metropolitana, que agora passam por grande valorização com a obras feitas pelo Governo. A RF Participações, que está em nome de Flora Atherino Leite, é a mesma empresa
}

\footnotetext{
38 http://www.gazetadopovo.com.br/politica/parana/executivo-da-jbs-delata-r-1-milhao-entregue-emespecie-a-irmao-de-richa-e9ehss7gbfldzxe1p057166hd

39 https://www.bonde.com.br/bondenews/politica/empresaria-afirma-que-pagou-propina-a-pepe-richa308612.html

${ }^{40} \mathrm{https}$ ://contraponto.jor.br/escandalo-de-paranagua-repete-o-metodo-na-rm-ii/
} 
que reúne a Green Logística - que comprou a área do Eixo Modal de Paranaguá. E Flora Atherino Leite é a mulher de Jorge Atherino ${ }^{41}$.

\section{Operação integração da Lava Jato}

Em março de 2016, o Superior Tribunal de Justiça autorizou o primeiro inquérito contra o governador Beto Richa sobre o esquema de corrupção da Receita Estadual, fruto da Operação Publicano. A acusação é de que R \$ 4,3 milhões desviados tenham financiado a reeleição do tucano. Em março de 2017, Richa ganha o segundo inquérito na Operação Superagui que investiga licenças ambientais concedidas em Paranaguá. Logo depois, aparece em delações da Odebrecht e JBS.

Em 22 de fevereiro de 2018, a Polícia Federal prendeu seis pessoas na fase 48 da Operação Lava Jato, batizada de Integração. Foi a primeira fase da Lava Jato em 2018 e apurou crimes como corrupção, fraude a licitações e lavagem de dinheiro na gestão das concessões de rodovias federais no Paraná, casos de corrupção ligados aos contratos de concessão de rodovias federais no estado que fazem parte do Anel da Integração, hoje composto por 27 praças de cobrança. A investigação apurou desvios de pelo menos R $\$$ 63 milhões. Policiais federais cumpriram 55 mandados de busca e apreensão e seis de prisão temporária em quatro estados: Paraná, Santa Catarina, Rio de Janeiro e São Paulo.

Dados da quebra de sigilo bancário da ECONORTE demonstraram que, entre 2005 e 2015, a concessionária recebeu aproximadamente $\mathrm{R} \$ 2,3$ bilhões provenientes de tarifas pagas pelos usuários. Deste valor, $\mathrm{R} \$ 343$ milhões foram repassados para uma subsidiária integral em contratos de conservação. Da subsidiária integral, R \$ 110 milhões foram repassados a holding do grupo e, pelo menos $\mathrm{R} \$ 63$ milhões a empresas de fachada ou sociedades cuja prestação de serviços ou entrega de produtos não foi comprovada. A Receita Federal conseguiu identificar pelo menos $\mathrm{R} \$ 56$ milhões em desvios por meio de serviços fictícios. Outras perícias técnicas realizadas pelo MPF demonstraram superfaturamento nos valores das obras das concessionárias constantes na proposta comercial. Conforme o laudo técnico, que utilizou como parâmetro a tabela do Sistema Nacional de Pesquisa de Custos e Índices da Construção Civil (Sinapi), da Caixa Econômica Federal, em alguns itens das planilhas houve sobrepreço de $89 \%$ em relação

\footnotetext{
${ }^{41}$ https://contraponto.jor.br/o-sempre-presente-jorge-atherino-o-grego/
} 
ao valor de mercado. Para o MPF, essa "gordura" (excedente) era usada para pagamentos indevidos ${ }^{42}$.

De acordo com os procuradores, o Tribunal de Contas da União (TCU) analisou os contratos em 2012 e encontrou inconsistências. O DER então contratou uma empresa terceirizada para fazer um estudo técnico. A empresa sugeriu redução da tarifa em 18\%, mas o DER descartou o estudo, solicitou uma avaliação interna e a Econorte foi favorecida por dois termos aditivos e um termo de ajuste que aumentaram a tarifa paga pelo usuário em mais de 25\%. De acordo com o MPF, a Econorte repassou pelo menos R \$ 63 milhões para empresas de fachada ou sociedades cuja prestação de serviço ou entrega de produtos não foi confirmada. Uma das concessionárias investigadas tinha uma empresa irmã do mesmo grupo e essa empresa só existia em função da concessionária. “100\% da receita corrente”, segundo o auditor da Receita Federal Roberto Lemos. "A concessionária terceirizava as despesas operacionais ordinárias". O procurador Diogo Castor de Mattos afirmou durante a coletiva de imprensa, no entanto, que o valor desviado "pode passar de R\$ 100 milhões". "Mas isso demandaria estudos técnicos mais aprofundados" $" 43$.

$\mathrm{Na} 36^{\mathrm{a}}$ fase da Lava Jato, a Econorte apareceu pela primeira vez. Em 2016, batizada de Operação Dragão, a ação mirou Adir Assad e Rodrigo Tacla Duran, suspeitos de terem movimentado de forma ilegal $\mathrm{R} \$ 50$ milhões. Na época, a concessionária foi apontada como suspeita de participar de um esquema de lavagem de dinheiro. Conforme o procurador Diogo Castor de Matos, Tacla Duran usava o escritório de advocacia dele e empresas prestadoras de serviço para fins ilícitos. A Econorte depositou R\$ 1.005.714,50 em favor de Tacla Duran entre 2012 e 2014. Já Adir Assad, segundo o MPF, tinha uma "estrutura gigantesca" de produção de dinheiro em espécie, segundo os procuradores. Empresas relacionadas ao Grupo Triunfo depositaram R\$ 26 milhões para empresas de fachada do operador financeiro. A $48^{\text {a }}$ fase ocorre dentro do âmbito da colaboração premiada dele com a força-tarefa. Assad ajudou a identificar pessoas envolvidas no Grupo Triunfo, especialmente dono da construtora: Luiz Fernando Wolff de Carvalho. Ele é tio da advogada Rosângela Wolff Moro, esposa do Juiz Sérgio Moro. Família jurídica com desembargadores, juízes e grandes escritórios de advogados. O empresário é apontado como um dos articuladores de esquemas de superfaturamento e

\footnotetext{
42 http://politica.estadao.com.br/blogs/fausto-macedo/casa-civil-de-beto-richa-e-alvo-de-buscas-da-48-afase-da-lava-jato/

${ }^{43} \mathrm{https}$ ://www.cartacapital.com.br/politica/a-lava-jato-atinge-o-governo-de-beto-richa-no-parana
} 
de distribuição de propinas oriundas do sistema de pedágio rodoviários e que, direta ou indiretamente, mantinha ligações com o operador Tacla Durán, foragido na Espanha.

Luiz Fernando Wolff de Carvalho, nascido em 21 de junho de 1953, graduou-se como Engenheiro Civil pela Universidade Federal do Paraná e como Economista pela FAE - Faculdade Católica de Administração e Economia. Atuou como estagiário, foi Engenheiro de Obras e Superintendente na EBEC - Engenharia Brasileira de Construções S.A. até 1983. De 1983 a 1987 foi Diretor Superintendente da C.R. Almeida Engenharia e Construções S.A.. Em dezembro 1987 adquiriu a empresa Construtora Malachias Ltda e, em janeiro 1988, associou-se à Construtora Triunfo S.A.

A $36^{\circ}$ Operação da Lava Jato denominada Vôo do Dragão já envolveu a Construtora Triunfo de Luiz Fernando Wolf Carvalho, alvo da Operação Dragão, doou R\$ 12 milhões a candidatos do PT na campanha de 2014. Os principais beneficiários foram Dilma Rousseff, Gleisi Hoffmann e Delcídio do Amaral. Dilma oficialmente R \$ 9 milhões, enquanto Gleisi recebeu R \$ 2 milhões ( $\$$ \$ 500 mil via Diretório Regional) e Delcídio levou R\$ 1 milhão.

\begin{abstract}
$\mathrm{Na}$ lista de beneficiados pelas doações da empresa desde 2008 estão Beto Richa (PSDB), Gleisi Hoffmann (PT) e Roberto Requião (PMDB). Nos últimos dez anos foram doados $\mathrm{R} \$ 2,5$ milhões. Quem mais recebeu dinheiro da construtora foi Gleisi Hoffmann. A senadora recebeu R \$ 1,5 milhão em 2014, quando disputou o governo do estado. Já Beto Richa recebeu R \$320 mil da construtora, sendo R \$ 300 mil quando disputou a prefeitura, em 2008 e R \$ 20 mil, na disputa estadual de 2014. Além disso, em 2010, a construtora doou R \$ 500 mil ao PSDB do Paraná. A informação está em um relatório apresentado pelo MPF em 2014, quando começaram as investigações dos contratos de pedágio no Paraná. Já o senador Roberto Requião recebeu $\mathrm{R}$ \$ 50 mil da construtora em 2014, quando também disputou o governo do Paraná. Em 2014, a empresa também doou R \$ 50 mil para a campanha do deputado estadual Rasca Rodrigues (PV). O mesmo valor foi doado para Omar Sabbag Filho, que disputou uma cadeira na Assembleia Legislativa ${ }^{44}$.
\end{abstract}

Além de Wolff, tiveram pedidos de prisão dois operadores diretamente ligados à Beto Richa. Nelson Leal Júnior, diretor-geral do Departamento de Estradas de Rodagem no Paraná (DER-PR) e Carlos Felisberto Nasser, assessor da Casa Civil.

Nelson Leal Júnior é natural de Paranavaí - filho de Nelson Leal e Lecir Lacroix Leal. Seu pai foi ex-engenheiro-chefe do DER em Paranavaí. Casado com Georgia Junqueira Leal, com quem tem os filhos André Junqueira Leal e Bruna Junqueira Leal. É formado em Engenharia Civil pela Universidade Federal do Paraná (UFPR), com

44 http://www.gazetadopovo.com.br/blogs/joao-frey/2018/02/22/lava-jato-nos-pedagios-empresainvestigada-ja-doou-para-richa-gleisi-e-requiao/ 
especialização em Gestão Empresarial. Sua biografia é marcada por suas atuações como chefe do Departamento de Registro e Fiscalização do CREA-PR (1989-1995), diretor Financeiro do Instituto de Engenharia do Paraná (1996-2000), conselheiro do CREA (1998-2004), presidente da Federação das Associações de Engenharia e Arquitetura do Estado do Paraná (2000-2003), Secretário de Obras da Prefeitura Municipal de Curitiba (2003-2006), Diretor Superintendente da empresa Canet Júnior S/A Desenvolvimento Imobiliário (2006-2012) e Diretor Geral do Departamento de Estradas de Rodagem do Paraná - DER-PR (2013 até 2018) ${ }^{45}$. Foi secretário de Obras de Richa na prefeitura de Curitiba e, desde 2013, era o chefe do DER, responsável pelo contato com as empreiteiras nas obras tocadas pelo estado e pelas negociações com as concessionárias de pedágio. O DER é subordinado à Secretaria de Infraestrutura e Logística (SEIL), comandada por José Richa Filho.

Foram presos junto com Nelson Leal o ex-funcionário do DER Oscar Alberto Gayer da Silva, Wellington de Melo Volpato, sócio da Eco Sul Brasil Construtora, Hélio Ogama, diretor-presidente da Triunfo Econorte, Leonardo Guerra, administrador da empresa Rio Tibagi, e Sandro Antônio de Lima, diretor financeiro da Triunfo Participações. Um dos investigados - Paulo Garcez Beckert - está fora do país. Nasser alvo de um mandado de busca e apreensão pela idade avançada.

Conforme o Ministério Público, Leal contrariava estudos técnicos do próprio departamento para liberar aumento da tarifa nas praças de pedágio. Em um dos casos, um estudo do DER sugeriu a redução tarifária no pedágio em 19\% e, em contrapartida, firmou-se um aditivo em que a tarifa subiu 24\%, segundo os procuradores. Em alguns itens, o superfaturamento da concessionária chegou a $89 \%$. "Ele retificava atos, lavrava aditivos com essa empresa, aumentando a tarifa de forma totalmente desproporcional, contrariando estudos encomendados pelo próprio DER. Paralelamente a essa rede de pagamentos a empresas de fachada, fazia gastos em espécie com imóveis de luxo e iates, totalmente incompatível com a renda declarada à Receita Federal”, afirmou o MP. Em algumas das ocasiões, os aluguéis iates eram pagos por empresários que tinham contratos com o $\mathrm{DER}^{46}$.

\footnotetext{
45 https://paranavai.portaldacidade.com/noticias/educacao/engenheiro-do-der-nelson-leal-junior-recebetitulo-de-cidadao-benemerito

46 https://oglobo.globo.com/brasil/assessor-da-casa-civil-no-parana-sacou-33-milhoes-em-dez-anos-
} 22421901 
Entre os imóveis de luxo investigados está um apartamento no Condomínio Don Alfonso, em Balneário Camboriú, litoral de Santa Catarina, adquirido por Nelson Leal e Georgia Junqueira Leal. O imóvel foi comprado por $\mathrm{R} \$ 2.580 .000,00$ e não foi declarado no Imposto de Renda do investigado. O MPF afirma ainda que, quando ia pra Santa Catarina, Nelson costumava alugar barcos para passear com amigos e família. Segundo as investigações, a preferência era por embarcações grandes, com dois quartos, uma suíte, banheiro e cozinha. A diária chega a custar $\mathrm{R} \$ 16 \mathrm{mil}^{47}$. No curso das investigações foram decretadas quebras de sigilo fiscal e bancário de Nelson Leal Júnior, de sua esposa Georgia Junqueira Leal e da empresa Junqueira Leal Arquitetura e Engenharia Ltda. A vice-governadora Fernando Richa também faz parte da família Junqueira, uma antiga família de fazendeiros e latifundiários em Minas Gerais e em São Paulo desde o período colonial.

O assessor da Casa Civil Carlos Felisberto Nasser foi alvo de um mandado de busca e apreensão no Palácio Iguaçu. Na Casa Civil, a remuneração bruta de Nasser é de $\mathrm{R} \$$ 9.643,81. O delegado Igor de Paula, da Polícia Federal (PF), disse que a investigação se limitou à mesa do funcionário. $\mathrm{O}$ assessor teria recebido $\mathrm{R} \$ 2,8$ milhões do esquema. Ele teria uma empresa de marketing de fachada para receber dinheiro de empresas ligadas ao pedágio do Paraná. Com 78 anos de idade, Nasser é funcionário comissionado da Casa Civil da gestão Beto Richa (PSDB) ao menos desde fevereiro de 2013. Pela idade avançada, ele não foi preso durante a operação, mas sua mesa no Palácio Iguaçu foi revistada pela PF, para cumprimento de um mandado de busca e apreensão. O MPF havia pedido "a prisão preventiva ou subsidiariamente a prisão temporária" de Nasser, mas o juiz federal Sergio Moro indeferiu o pleito. O MPF aponta que Nasser recebeu, através da empresa Power Marketing, pagamentos das empresas Rio Tibagi e Triunfo Participações, ligadas à concessionária Econorte. Nasser é irmão de Ercília Maria Nasser Viecili, sócia majoritária e administradora da empresa Power Marketing Assessoria e Planejamento Ltda. desde julho de 2011. Mas o próprio Nasser era o titular e administrador da empresa até tal data. Em consulta à Relação Anual de Informações Sociais (RAIS), o MPF constatou que a Power Marketing não teve empregados entre 2005 e 2016. Entre 2007 e 2015, a Power Marketing recebeu R\$2.267.565,51 da Rio Tibagi. Também recebeu R\$ 615.000,00 da Triunfo Participações em transferência bancária

47 https://contraponto.jor.br/wp-content/uploads/2018/02/mpf-opera\%C3\%A7\%C3\%A3ointegra\%C3\%A7\%C3\%A3o.pdf 
datada de junho de 2008. A Rio Tibagi e a Triunfo Participações, anota o MPF, são as únicas fontes de pagamentos para a Power Marketing a partir de 2008.

\section{Conclusão}

Com uma grande rede de famílias no controle do governo, da assembleia legislativa, Tribunal de Contas, Tribunal de Justiça, Ministério Público, entre outras instituições, os poderes passam a ser cúmplices em busca de vantagens e privilégios. $\mathrm{O}$ nepotismo generalizado nas instituições gera uma série de atividades para obtenção de vantagens pessoais, para si ou para terceiro. Não são apenas recompensas financeiras, mas vantagens de qualquer tipo, como apropriação do patrimônio público pelo privado por grupos que utilizam o Estado em processos de troca de favores, negociação de benefícios relacionados a cargos ou funções públicas, ou exercem influência sobre estes, visando ao desvio de recursos públicos.

Formado por um núcleo duro de nepotismo, o governo Beto Richa organizou diversas atividades aparentemente irregulares na Secretarias de Educação, na Receita Estadual, no Porto de Paranaguá e no setor ligado a obras. Seu maior operador era seu primo, Abi Antun, porém seu irmão Pepe Richa também aparece em denúncias, bem como secretários de confiança, membros do partido e sócios da família. Apesar das investigações, em 2018, quatro membros da família Richa disputarão as eleições de outubro, com Beto Richa para o Senado, Pepe Richa concorrerá à Câmara, o filho Marcello Richa e o primo Marcos Traad buscarão uma cadeira na Assembleia Legislativa. 